\title{
Hyperinflation: A Theory On The Ignorance Concerning Money And Interest
}

\author{
José Villacís González, University of San Pablo-CEU, Spain
}

\begin{abstract}
In cases of hyperinflation the exchange rate varies at a rate close to the rate of inflation and the savings present in the financial system lose their capacity to be invested. One could say that there is a demand for the stongest foreign currency for transactional and speculative purposes that is equal to the traditional demand for money. At the same time, savings lose their purchasing power due to the speed and fluctuations in the rate of increase of prices.
\end{abstract}

Keywords: exchange rate, financial system.

\section{INTRODUCTION}

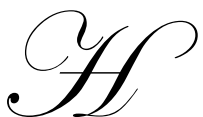

yperinflation is characterised by a rapid rise in prices and by the speed and irregularity of that increase. Periods of hyperinflation lead to loss of confidence and then to panic in the money markets, generating a massive demand for foreign currency, particularly for the strongest foreign currency. Paradoxically, there is the domestic currency in cases of hyperinflation, given that people lose confidence in it at the same speed at which they put their confidence in the strongest foreign currency, for example, the US dollar. The domestic currency is normally used to make payments but is increasingly rejected by payees in favour of foreign currency. This is the demand for money for transactional purposes. Money is also required for speculative purposes to protect those holding it against the loss in value of their savings.

The exchange rate can change at the same speed as the domestic rate of inflation, faster than this rate, or more slowly. This is the question we set out to examine.

In the same way in which there is a money market versus a financial market, as defined in the LM curve, there is also a currency market versus a domestic money market.

In the financial system, savings lose their purchasing power due to the speed of inflation, with the result that they take refuge in speculating in hard and financial assets. This is one-way traffic and prevents those savings from being invested productively.

The supply of and demand for currency, speculative hard assets and budget deficits cause variations in the supply of and demand for money, which causes fluctuations in the interest rates, the so-called 'yo-yo' effect, which also discourages investment.

The domestic currency is employed less and less in investment and production, thereby accelerating the imbalance between the money supply and production.

\section{EXCHANGE RATES}

In periods of hyperinflation, prices rise very fast because the available money supply itself rises very fast and, given that this situation is dynamic and ongoing in time, the relation between the domestic money supply and other currencies is also continuous. What this means is that more domestic currency is available for a unit of account of the leading foreign currency. This can occur for a multitude of reasons, but we can simplify by saying that this is 
made possible for the simple reason that proportionally, more domestic money is generated than, in terms of real growth, foreign currency is available.

Bidding for available foreign currency and the demand for this, paid for in domestic currency, is what establishes the exchange rate. So, changes in the exchange rate can be understood as fluctuations in the demand for and supply of foreign currency.

\section{DEMAND FOR FOREIGN CURRENCY}

Demand for foreign currency arises for three reasons: first, the need to pay for imports and exports and other balance-of-payment transactions, i.e. for transactions arising out of national spending in relation to the rest of the world; secondly, because of rising transactions demand within a domestic economy which is experiencing hyperinflation; and, thirdly, for purposes of speculation.

There is a formal and even conceptual parallel between this market and the orthodox money market that helps to explain the LM curve. Let us look for a moment at the two cases. In doing so, we should add to the equation the overreaction of countries suffering hyperinflation. This overreaction is the degree of desperation experienced by the holders of asset portfolios when trying to exchange domestic currency for foreign currency by all means available.

\section{The demand for currency in the balance of payments}

Currency is needed first of all to pay for imports. As countries also export, foreign currency is also needed to pay for exports to the extent that these exceed imports $(\mathrm{X}-\mathrm{M})$. This analysis tells only half the story because it looks exclusively at the trade balance. What generally happens when countries suffer hyperinflation is that on one side exporters do whatever they can to be paid in foreign currency as opposed to domestic currency. And at the same time the exporters of other countries also insist on being paid in the strongest currency and on no account in the depreciated currency of the importing country. This results in a market of supply and demand for foreign currency which depends, leaving aside the capital balance, on a surplus or deficit in the trade balance. Seen in this light, a point of equilibrium or stability will only be reached if there is a foreign trade surplus. If, however, there is a deficit in the trade balance, the depreciation of the domestic currency will gather even greater speed than that produced by the overreaction. This explains why currencies tend to depreciate faster than the domestic rate of inflation.

\section{Transactions demand}

The demand for money to pay for transactions depends of the level of disposable income $(\mathrm{L}(\mathrm{Y}))$. Transactions demand for currency also depends on the level of disposable income, but not on all disposable income, only part, $\mathrm{Y}^{*}$, expressed as $\mathrm{Y}^{*}<\mathrm{Y}$. This is due to the lack of confidence of sellers in the domestic currency, whose rate of depreciation is difficult to forecast. Sellers want to be paid in a strong foreign currency instead of the domestic currency. Most major contracts are paid in foreign currency on the understanding that this will appreciate at least as fast as the domestic rate of inflation.

Not all, but a significant number of domestic transactions are paid for in foreign currency, bought on the currency markets, in view of the intrinsic needs of transactional operations. For this reason it is held that such purchases vary according to the partial disposable income: $\mathrm{Y}^{*}$. At the same time, the sellers who receive the currency, wherever possible act as speculators, thereby driving the overreaction in the currency market. If this trend sets in seriously, the domestic currency depreciates faster than the rate of inflation, however high this may be.

Speculative demand

The greatest concern of those holding investment portfolios, i.e. consumers, savers, speculators, is to maintain the value of their real balances $(\mathrm{M} / \mathrm{P})$. To achieve this they must keep the nominal value of their portfolios at the same level as prices, such that $\Delta \mathrm{M}>\Delta \mathrm{P}$ or $\Delta \mathrm{M}=\Delta \mathrm{P}$. The easiest way of maintaining their real balances at least constant is to convert the nominal balances into currency. To what extent is it legitimate to differentiate 
disposable income balances from savings balances and savings balances from speculative balances in terms of money suitable for being exchanged for currency? Disposable income balances, given the daily needs of living, rarely offer this possibility. Savings, however, as they occupy for a short space of time a place in the financial system, are monetary values apt for being used to protect their value against inflation by being converting into foreign currency; they can also be exchanged for hard and speculative assets that do not form part of the current producing period.

Given that the feature that defines hyperinflation is not just the absolute rise in prices but also the speed and volatility at which this takes place, the savings within the financial system that proceed from the current period, and which derive from disposable income, rapidly become foreign currency obtained in the currency market. The net result is a synchronisation, perhaps better defined as a confusion, between the financial system and the currency market. However quickly savings can be generated and take their place in the financial system, it is always long enough for them to lose their purchasing power in terms of parity with foreign currency. The resulting urgency to exchange them creates the overreaction which makes the rate of depreciation of the domestic currency exceed the real rate of domestic inflation.

\section{SUPPLY OF THE STRONGEST CURRENCY}

It is interesting to ask at this stage why suppliers of, for example, the US dollar are prepared to exchange them for a depreciated and depreciating currency. The answer is speculation, that same speculation that drives demand for foreign currency on the part of private sector suppliers. In the case of institutional providers, the reason why the central bank of a country whose currency is depreciating is prepared to do this is to maintain the nominal exchange rate.

Suppliers of foreign currency offer it at its true value, i.e. M/P, and thus their forecast of the rise in prices is crucial when it comes to offering that supply. Given that one of the features of hyperinflation is the fluctuation and speed of the increase in prices, together with the overreaction on the part of buyers, the supply of foreign currency frequently dries up. For there to be an overreaction it is necessary, as noted above, for the expectation of the rate of increase in prices to be nil, in consequence of the fluctuations in said increase in prices. On the other hand, if the supplier is the central bank, participants in the economy know that the bank will soon exhaust its stock of strong foreign currency in its efforts to maintain a stable exchange rate. This awareness leads to the overreaction in the marketplace which causes a rise in the demand for foreign currency. Again, the net result of this is that in relative terms there is a greater demand for foreign currency that for domestic currency, leading to accelerated depreciation of the domestic currency, which is the rate of inflation.

\section{CAUSE-AND-EFFECT REVERSAL}

People who try to steal a march on the markets by anticipating events very often provoke changes in the exchange rate that influence the overreaction.

These arguments have much to do with the so-called 'cause-and-effect reversal', which occurs when certain behaviour appears to have consequences that are, in reality, its causes. It is like people buying winter coats before winter starts. The two phenomena are related but winter is the not the consequence of people buying winter coats but the cause.

Let us look at the following cases. Suppliers of foreign currency believe, rightly, that inflation will accelerate and that there will therefore be increased demand for foreign currency in an effort to offset the loss in real terms. They also know that the terms offered will decrease $(\mathrm{M} / \Delta \mathrm{P})$. What they then do is to restrict the supply in real terms of the strong currency with a view to provoking faster depreciation of the domestic currency and an appreciation of the foreign currency that outpaces the rate of inflation. This situation will reveal to all the inability of the central bank and the holders of foreign currency to support the domestic currency, which will cause even faster depreciation in absolute terms than the underlying level of devaluation. Another example: a forecast of inflation leads to advance demand for goods and services causing tension in the money markets because more cash is required to make these purchases. The monetary authority receives this information and prints more money to allow 
these purchases to take place and, as a result, inflation accelerates. Faced with unexpectedly fast inflation, the holders of cash portfolios try to switch into foreign currency, with the result that the rate of inflation climbs to a level that at least parallels the appreciation of the foreign currency if it does not surpass it.

The overreaction and the accelerated depreciation of a domestic currency against a strong foreign currency are directly related to two key central-bank policies that are, in fact, contradictory. The first is that of trying to limit inflation by exercising a contractive monetary policy; the second is to create more money when the financial system cries out for it. Each in their way, both policies contribute to making the rate of inflation irregular and unpredictable.

\section{CONCLUSION}

What we are looking at in reality is a market made up of a strong currency that is in demand and is available in countries suffering hyperinflation. It is similar in form and concept to the money market made up of the demand for money for transactional purposes and the speculative demand arising from the predicted rate of inflation. Both demands and available supply of foreign currency act simultaneously, resulting in an overreaction, which is the level of sensitivity to the rejection of the depreciated currency.

Not only does the domestic currency depreciated against the strong currency; also the rate of depreciation exceeds that of inflation. This is due partly to the overreaction and partly to the fact that the availability of the strong currency is considerably less than the rate of increase in the depreciation of the currency concerned.

Demand for foreign currency for purposes of speculation has a very important role to play in this because it has a direct bearing on the level of savings in the financial system which, in an economy undergoing rapid inflation, quickly loses its purchasing power. To protect savings in real terms, investors buy the strong currency faster and faster, thereby accelerating the rate of depreciation of their own currency.

Very often the sensation or overreaction felt in the money markets when a currency begins to appreciate means that that currency appreciates faster than the underlying rate of inflation. The same happens in reverse.

This paper contains two arguments: one is that in cases of hyperinflation the irregularity of the rate of inflation or variations in the speed of inflation play a very important role; the other is that it is an overreaction by market players to the depreciation of their own currency that makes them buy foreign currency to excess.

\section{AUTHOR INFORMATION}

Jose Villacis Gonzalez has a $\mathrm{PhD}$ in economic science; degree in political science and sociology; lecturer in economy at the University San Pablo-CEU; author of various books: Macroeconomía, Microeconomía, Política Monetaria y Política Fiscal; El Origen de la Macroeconomía en España; La Teoría de las Disponibilidades, del Interés y de la Renta; La Máquina de la superación de Leviathan; Germán Bernacer y el Círculo de Alicante.

\section{REFERENCES}

Parte de las ideas de este trabajo se deben a Enrique Arriol Olalla estudiante de la Universidad CEU San Pablo.

1. Azariadis,C. (1975): “A Reexamination of Natural Rate Theory", American Economic Review, 71: 946-60.

2. Barro, Robert J. (1977): "Unanticipated Money Growth and Unemployment in the United States", American Economic Review, 67: 101-15.

3. Barro, Robert..(1980): “A Capital Market in an Equilibrium with Restricted Borrowing”. Econometrica, 48:1393-417

4. Bernácer Germán (1916): "Sociedad y Felicidad”. Edit.Beltrán. Madrid (Books), 1916.

5. (1922): "La Teoría de las Disponibilidades". Revista Española de Economía . Madrid. Barcelona.(Artícle).

6. 1945), "La Doctrina Funcional del Dinero". Edit.Consejo Superior de Investigaciones Científicas.Madrid (Books), 
7. Blinder, Alan S.y Fisher, (1985): "Inventories, Rational Expectations, and the Business Cycle", Journal of Monetary Economics, 8: 277-304.

8. Baumol William.(1952): “The Transaction Demand for Cash:An Inventory Theoritic Approach”. Quaterly Journal of Economics, 66 noviembre.

9. Cagan, Phillips, (1956) "The Monetary Dinamics of Hiperinflation, en Studies in the Quantity Theory of Money", editado por Milton Friedman.Chicago:University of Chicago Press.

10. Feldstein Martin, (1980): "Comments on A Competitive Theory of Fluctuations and the Feastibility and Desirability of Stabilization Policy", En Rational Expectations of the Gramlih Study, Brooking Papers on Economic Activity, 1: 167-168.

11. Feige, E.(1964)."The Demand for Liquid Assets: A Temporal Cross-Section Analysis" . Englewood Cliffs, N.J.:Prentice-Hall.

12. Fisher, I.(1911) "Purchasing Power of Money", New York: Mc Millan.

13. Friedman M. (1956) : "The Quantity Theory of Money; A Restatement", en M.Friedman (Edi.) Studies in the Quantity Theory of Money, Chicago:Univerisity of Chicago Press.

14. Friedman M. (1968): "The Role of Monetary Policy", American Economic Review, 58:1-17.

15. Grossman,S., y Joseph E.Stiglitz (1981): “Information and Competitive Stock Prices", American Economic Review,66 246-53.

16. Hall, Robert E. (1976): "The Phillips Curvew and Macroeconomic Policy., in the Phillips Curves and Labor Markets”, editado por Karl Brunner y allan H.Meltzer. Carnegie-Rochester Conference Series on Public Policy number 1. Amsterdam:North Holland.

17. Hayek, F.A.(1945): "The Use of Knowledge in Society", American Economic Review, 35: 519-30.

18. Hicks, J.R.(1935): “A Suggestion for Symplifying the Theory of Money". Economica, 2 (february).

19. Iacocca L.; Novak W; "Iacocca. Autobiografia de um Triunfador".(1984), Ediciones Grijalbo,

20. Kearl, James.(1979): “Inflation, Mortgagges, Houssing”, Journal of Political Economy, 87: 1115-38.

21. Keynes, J.M.(1936): "The General Theory of Employment, Interest and Money". New York: Harcourt, Grace and World.

(1923) “A Tract on Monetary Reform", London Mc:Millan.

(1930)“A Teatrise on Money", London and New York: Mc Millan.

22. Klein, B. (1974):“The Competitive Supply of Money”, Journal of Money, Credit and Banking, 423-454.

23. Kuhn, Thomas S.(1970) :"The Structure of Scientific Revolutions"., 2..Edición.Chicago:University of Chicago Press.

24. Kydland, Finn E., y Edward C.Prescott: (1977):“Rules Rather than Discretion: The Inconsistency of Optimal Plans", Journal of Political Economy, 85: 473-91, (1980):“A Competitive Theory of Fluctuations and the Feseability and Desirability of Stabilization Policy”, en Rational Expectation and Economic Policy, editado por Stanley Fisher. Chicago:Chicago:National Bureau of Economic Research.

25. Laidler, D. (1966): "Some Evidence of the Demand for Money", Journal of Political Economy,74, 55-68. (1968) : "The Permanent Income Concept in a Macroeconomic Model", Oxford Economic Paper, 20 marzo,11-23.

(1973):- "Expectations,Adjusment and the Dynamic Response of Income to Policy Changes", Journal of Money, Credit and Banking, 4, 157-172. 1973.

26. Lintner, John (1965): “The Valuation of Risk Assets and the Selection of Risky Invesment in Stocks, Portfolios and Capital Budgets", Review of Economic and Statistic, 47:13-37.

27. Lucas, Robert E. Pr.(1972): "Expectations and the Neutrality of Money", Journal of Economic Theory, 4:103-24.

28. (1973): "Some International Evidence on Ouput-Inflation Trade-offs", American Economic Review,: 32634.

(1976): “Econometric Policy Evaluation: A Critique, in The Phillips Curve and Labor Markets", editado por Karl Brunner y Allan Meltzer.Amsterdam: North Holland.

(1977): "Undesttanding Business Cycles, inStabilization of the Domestic and International

Economy",editado por Karl Brunner y Allan Meltzer.Carnegie-Rochester Conference Series in Public Policy.Amsterdam:North Holland.

1978: “Unemployment Policy", American .Economy Review, 68: 353-7 
(1980) "Methods and Problem in Business Cycles Theory", Journal of Money,Credit and Banking, 12: 696715.

(1980): "Rules, discretion and the Roles of the Economic Advisor, in Rational Expectation and Economic Policy", editado por Stanley Fisher.Chicago:National Bureau of Economic Research.

29. Lucas, R.E. Jr. y T..J..Sargent.(1978): “After Keynesian Macroeconomics, in After the Phillips Curve:Persistence of High Inflation and High Unemployment". Federal Reserve Bank of Boston Conference, vol. 19, Boston:Federal Reserve Bank, pp.49-72.

30. Locke, J.(1692): "Some Considerations of the Consequences of the Lowering of Interest and Raising the Value of Money". Edit.London.

31. 33. McCallum,Bennet T.(1976): "Rational Expectations and the Natural Rate Hypothesis: Some Consistent Estimates", Econometrica, 44:43-52.

(1980): "Rational Expectations and Macoeconomics Stabilization Policy", Journal of Money,Credit and Banking, 12: 716-46.

32. Matthews,R.C.O.(1963): "Expenditure Plans and the Uncertainty Motive for Holding Money", Journal of Policital Economy,71(june),201-218.

33. Mayer, Thomas.(1978): "The Structure of Monetarism". New York: Norton.

34. Meltzer, Allan.(1978): "Monetarism,Keynesian and Quantity Theories, in The Structure on Monetarism", editado por Thomas Mayer.New York:Norton.

35. Meyer, P.A. y Neri, J.A.(1975): “A Keynes-Friedman Money Demand Function, American Economic Review,65, 610-623.

36. Mishkin, Frederik S.(1978): "Efficient- Market Theory: Implications for Monetary Policy", in Brookings Paper on Economy Activity, editado for Okun y G.L.Perry.Vol.3, pp 707-68. (1981) “Are Market Forecast Rational?”, American Economic Review,71: 293-306. (1981)"Monetary Policy and Long Term Interest Rates:And Efficient Market Approach", Journal of Monetary Economics, 7: 29-55.

37. Modigliani, F.Brumberg, R.E.(1954): "Utility analysis and the Consumption Funtion: An Interpretation of Cross-Section" Data, en K.K.Kurihara, Pos-Keynesian Economics, Londres, George Allen\&Unwin.

38. Musgrave,R..A..(1939): “The Voluntary Exchange Theory of Public Economy”, en Quaterly Journal Economy. (1959): “The Theory of Public Finance", Londres, McGraw-Hill.

39. Muth, John F.(1960): "Optimal Properties of Exponencially Weithted Forescast", Journal of the American Statistical Association, 55: 299-306.

(1961): "Rational Expectations an the Theory of Price Movements", Econometrica, 29: 315-35.

40. Nelson,C.R. y G.W.Schwartz. (1977):“On Testing Hypothesis That the Real Rate of Interest Is Constant”, American Economic Review, 67: 478-86.

41. Nerlove, Marc.(1958): “Adaptative Expectations and Cobweb Phenomena”, Quaterly Journal Economy, 73:227-40.

42. Oakeshott, Michael.(1962): "Rationalism in Politics". New York: Basic Books.

43. Okun, Arthur M.(1981): "Prices and Quantities". Washington D.C.: The Brooking Institution.

44. Patinking, Don.(1965): Money, Interest, and Prices; an Integration of Monetary and Value Theory, $2^{\circ}$ edition.New York: Harper\&Row. 1965.

45. Phelps, Edmund S. (1970): “The New Microeconomics in Employment and Inflation Theory", edition by Phelps.New York: Norton.

46. $\quad$ Phillips, A.W(1958):: "The Relation Between Unemployment and the Rate Of Change of Money Wage Rates in the United Kindgdom", 1861-1957, Economica,25: 283-94.

47. Prescott, Edward C.(1977): “Should Control Theory Be Used for Economics Stabilization?” in Optimal Policies, Control Theory and Technology Exports, editado por Karl Brunner y Allan Meltzer. CarnegieRochester Conference Series on Public Policy.Amsterdam: North Holland.

48. Radner, Roy. 1979): "Rational Expectations Equilibrium: Generic Existence and the Information Revealed by Price", Econometric $a$, 47:655-78.

49. Samuelson, Paul A..(1953): "Foundations of Economic Analysis", Harvard university Press-Cambridge. (1965): "Proof Properly Anticipated Prices Fluctuate Randomly", in The Collected Scientific Paper of Paul A.Samuelson, edited Robert Merton, vol.3.Cambridge, Mass.:Mass.: M.I.T.Press. 
50. Sheffrin,Steven M.(1979): “Uninticipated Money Growth and Duput Fluctuations, Economic Inquiry”,17: 1-13.-1983. Rational Expectations. Cambridge University Press, Cambridge,England.

51. Tobin, James,(1977): "Money and Economic Growth", Econometrica, 33:671-84.

(1977): “How Dead is Keynes?”, Economic. Inquiry, 15: 459-68.

(1981): "The Monetarist Counter-Revolution Today-An Appraisal", Economic Journal, 91: 29-42.

52. Villacís, José.(1987): “Política Monetaria y Fiscal: Una Paradoja de los Subrogados del Dinero". In Revista de Derecho Financiero y de Hacienda Pública. Volumen XXXVII, number 191 (septiembreoctubre).Madrid.

(1989): “Consecuencias Fiscales Heterodoxas en una Economía en Desocupación". In Revista de Derecho Financiero y de Hacienda Pública.Volumen XXXIX.Number 199 (enero-febrero).Madrid.

(1990): "La Política Fiscal No Existe". In Revista de Derecho Financiero y Hacienda Pública. Volumen XL-Number 205 (enero febrero).Madrid.

(1992) "La Oferta Agregada como Función de la Demanda Agregada Permanente". In Revista de Derecho Financiero y de Hacienda Pública. Volumen XLII-Número 219 (mayo-junio).Madrid.

\section{NOTES}


NOTES 